\title{
TOWARD TRANSLANGUAGING AS LINGUISTIC AND PEDAGOGY PRACTICES IN A PRESTIGIOUS BILINGUAL EDUCATION CONTEXT
}

\author{
Translinguagem como prática linguística e pedagógica na educação bilíngue \\ de elite
}

\author{
Ana Letícia Souza GARCIA \\ Instituto Federal de Goiás \\ Mestranda, Universidade Federal de Goiás \\ analeticiasg@gmail.com \\ https://orcid.org/0000-0002-2233-201X
}

RESUMO: Este artigo tem como objetivo analisar o uso do repertório linguístico no contexto de uma escola de educação bilíngue de elite (Português/Inglês) na cidade de Goiânia, estado de Goiás, no CentroOeste do Brasil. As teorizações que embasam este estudo são as concepções e papéis da L1/L2 nas interações e colaborações entre estudantes e professor/a nas aulas de inglês (DULAY; BURT; KRASHEN, 1982; MCLAUGHLIN, 1992; FIGUEIREDO, 2005; HARSEJSANI; RAYATI; YAQUBI, 2011); o conceito de ZPD (FIGUEIREDO, 2006) e scaffolding (FIGUEIREDO, 2006); e a concepção de translinguagem como alternativa para as práticas linguísticas e pedagógicas no ensino bilíngue de elite (BLACKLEDGE; CREESE, 2014; GARCÍA, 2009; GARCÍA; SELTZER, 2015; GARCÍA; WOODLEY, 2015). Para discutir o material empírico gerado em uma atividade oral na aula de língua inglesa, as seguintes perguntas guiaram a investigação: a) a L1 pode ser uma ferramenta ou scaffolding para que a L2 seja aprendida? b) por que a translinguagem em aulas bilíngues pode ser uma possibilidade para práticas linguísticas e pedagógicas mais heteroglóssicas? O aporte metodológico utilizado é a abordagem qualitativa interpretativista (DENZIN; LINCOLN, 2018). Os resultados mostram que, na maior parte do tempo, as práticas translíngues ajudam no desenvolvimento e ampliação do repertório linguístico dos/as alunos/as.

PALAVRAS-CHAVE: Translinguagem; Práticas translíngues; Educação bilíngue; Educação bilíngue de elite.

\begin{abstract}
This present study aims at analyzing the use of linguistic repertoire in a prestigious bilingual elementary school (Portuguese/English) context in the city of Goiania, state of Goias, Midwest of Brazil. The theorizations underpinning the investigation are the concept and role of L1/L2 in the interaction and collaboration among
\end{abstract}


students and teacher in English classes (DULAY; BURT; KRASHEN, 1982; MCLAUGHLIN, 1992; FIGUEIREDO, 2005; HARSEJSANI; RAYATI; YAQUBI, 2011); the concept of ZPD (FIGUEIREDO, 2006) and scaffolding (FIGUEIREDO, 2006); and the concept of translanguaging as an alternative to linguistic and pedagogy practices in prestigious bilingual education classes (BLACKLEDGE; CREESE, 2014; GARCÍA, 2009; GARCÍA; SELTZER, 2015; GARCÍA; WOODLEY, 2015). To discuss the empiric material generated in an oral activity in an English class, the following questions guided the study: a) is it possible to use the students' L1 as a tool/scaffolding to develop their L2?; b) why translanguaging in bilingual classes can be a possibility to enable more heteroglossic linguistic and pedagogy practices? This paper falls into the scope of the interpretive qualitative research (DENZIN; LINCOLN, 2018). The results showed that, most of the time, translanguaging practices help the students develop their linguistic repertoire.

KEYWORDS: Translanguaging; Linguistic practices; Bilingual education; Prestigious bilingual education.

\section{INTRODUCTION}

Our view of bilingual education is complex, like the banyan tree, allowing for growth in different directions at the same time and grounded in the diverse social realities from which it emerges.

(GARCÍA, 2009, p. 17)

The number of prestigious bilingual elementary schools in Brazil has increased lately, however, most of them are private, with high tuitions, turning into a very restricted type of education in which only elite groups have access. As a result, a significant number of students enrolled in prestigious bilingual schools in Brazil comes from the upper class. Globalization has been a key factor for parents to choose this type of schools, maybe because of the belief that their children are going to be more prepared to compete for better jobs or have more opportunities to study abroad. According to García (2009, p. 112), "the social elite have always had experience with bilingual education", for example, in colonial contexts their children were often taught the language of power through schooling. The author also highlights that in Europe, Latin America, Asia, and Africa upper class family usually sends their children to bilingual schools in order to learn prestigious languages, such as, French, German, or English.

Bilingual education is a simple label for a complex phenomenon, specially because 
of its ambiguity since it is used in a technical sense to refer to programs that incorporate the use of two languages in the classroom, but also to refer to any kind of program for bilingual children (CAZDEN; SNOW, 1990). In general, García and Lin (2016), define bilingual education as the use of two languages in education, often to make students bilingual and biliterate. As stated in García (2009), in globalized context of the twentyfirst century, the idea of learning a second language must be renewed by the idea of the bilingual whose communicative practices include translanguaging. Hence, the role that the first language (L1) ${ }^{1}$ plays in the process of learning ${ }^{2}$ a second language (L2) is still controversial nowadays. For some scholars and educators, the L1 is considered a villain that has to be fought in order to facilitate the learning of the L2 (DULAY; BURT; KRASHEN, 1982). However, the authors affirm that "in recent years, data have accumulated that place the L2 learner's first language in a more respectable, sometimes even valuable, place" (DULAY; BURT; KRASHEN, 1982, p. 96). Furthermore, as García and Woodley (2015, p. 139) highlight, talking about new debates, "some scholars speak about first languages, second languages, and even third languages, whereas seen through a heteroglossic lens, the language practices of bilinguals are not made up of two or more autonomous language systems".

In the context of bilingual education in Brazil, the scenario is even more opaque. For years the practice was to divide the number of hours to instruct students in the L1 and L2 (as an example, 50\% of the time for each language) in order to develop proficiency in the two languages. Nevertheless, it is something complicated to control or measure, once the students are bilingual and they interact all the time using their entire linguistic repertoire. According to McLaughlin (1992, p. 4),

\begin{abstract}
the use of the home language in bilingual classrooms enables the child to avoid falling behind in school work, and it also provides a mutually reinforcing bond between the home and the school. In fact, the home language acts as a bridge for children, enabling them to participate more effectively in school activities while they are learning English.
\end{abstract}

Thus, underpinning the investigation are the concept and role of L1/L2 in the interaction

\footnotetext{
${ }^{1} \mathrm{~L} 1$ and L2 in this paper are used to mark the chronological order of acquisition of a bilingual person, not as two autonomous language systems.

${ }^{2}$ Even though some scholars (KRASHEN, 1982) make a distinction between learning and acquisition, in this paper these terms are going to be used interchangeably.
} 
and collaboration among students and teacher in English classes (DULAY; BURT; KRASHEN, 1982; MCLAUGHLIN, 1992; FIGUEIREDO, 2005; HARSEJSANI; RAYATI; YAQUBI, 2011); the concept of ZPD (FIGUEIREDO, 2006) and scaffolding (FIGUEIREDO, 2006; GARCÍA, 2009); and the concept of translanguaging as an alternative to linguistic and pedagogy practices in bilingual education classes (BLACKLEDGE; CREESE, 2014; GARCÍA, 2009; GARCÍA; SELTZER, 2015; GARCÍA; WOODLEY, 2015). The aim of this study is to discuss the empirical material generated in two lessons in the context of a prestigious bilingual school (Portuguese/English) in Goiania, in the state of Goias, Midwest of Brazil, through the lens of the interaction that happened among students and teacher, in order to answer the following questions: a) is it possible to use the students' L1 as a tool/scaffolding to develop their L2?; b) why translanguaging in bilingual classes can be a possibility to enable more heteroglossic linguistic and pedagogy practices? This study falls within the scope of interpretive qualitative research in which the researcher is placed in a local context position where he/she can reveal and transform the world through interpretive practices (DENZIN; LINCOLN, 2018).

This paper is organized into four parts: in the first one, the study is introduced; in the second one, the theoretical background in which this investigation was grounded is given; in the third one, the context and also the discussion on the empirical material is presented; and in the fourth one, some final remarks are delineated.

\section{THEORETICAL BACKGROUND}

In the past, theories as the contrastive analysis hypothesis sought to understand the interference of the L1 in the L2 acquisition. Dulay, Burt and Krashen (1982) explain that contrastive analysis (CA) understood that the learner's L1 interferes as an obstacle in the L2 acquisition. According to them, the CA hypothesis postulates that, on one hand, "where structures in the L1 differed from those in the L2, errors that reflected the structure of the L1 would be produced" (DULAY; BURT; KRASHEN, 1982, p. 97) and those errors were labelled as negative transfer. On the other hand, if the structure was similar, resulting in correctness, it was labelled as positive transfer. However, the authors state that examination of the empirical material addressed to the CA hypothesis revealed that: 
1. In neither child nor adult L2 performance do the majority of the grammatical errors reflect the learner's L1.

2. L2 learners make many errors in areas of grammar that are comparable in both the L1 and the L2 - errors that should not be made if "positive transfer" were operating.

3. L2 learners' judgments of the grammatical correctness of L2 sentences are more related to L2 sentence type than to their own L1 structure.

4. Phonological errors exhibit more L1 influence than do grammatical errors (DULAY; BURT; KRASHEN, 1982, p. 97).

Additionally, if the main interference is regarding phonological aspects, accented speech does not cause lack of communication, but underdeveloped lexicon or a grammar error does. Then, we can infer that this is not a negative aspect caused by the L1.

In his study about the role of L1 in L2, Nazary (2008) emphasizes that nowadays it is common for English teachers use students' L1 as a tool for conveying meaning and he also says that if it is used appropriately, it can be very beneficial. Besides, the author carries on the discussion eliciting specific situations in which the L1 can be beneficial, such as explaining new vocabulary, giving instructions, providing further explanation on grammar, checking students' comprehension, among others. Furthermore, he differentiates three approaches related to the use of the L1 in the L2 classroom: Monolingual Approach, Bilingual Approach and Balanced Approach. For the followers of Monolingual Approach, the L1 should never be used, not even a single word, in L2 classes; the ones who use the L1 wisely are the proponents of Bilingual Approach; subsequently, he advocates towards a Balanced Approach, which shows the respect by the teachers for the students' L1, avoiding doing things that will make the L1 seems inferior to English, but, at the same time, will help the learners to develop their proficiency in L2.

To enhance the development of the L2, Paiva (1999, cited in FIGUEIREDO, 2005, p. 204) affirms that "interaction is of fundamental importance for any type of learning, especially regarding foreign language learning" ${ }^{3}$, thus, the teacher needs to provide opportunities so that the students may interact with classmates and also with the teacher. However, in classes where the students share the same L1, some teachers are afraid to propose pair or group activities claiming that they will shift to their L1 while they are in collaborative activities (HARSEJSANI; RAYATI; YAQUBI, 2012). Hence, this fear is 
more related to a monoglossic view of language practices and it is contrasted by a heteroglossic view of language where translanguaging practices among students in bilingual classes allows the students to use their entire linguistic repertoire. García and Seltzer (2015, p. 22), explain in a practical way the concept of translanguaging:

If you are bilingual and you own a smartphone, you will understand the difference between the concept of translanguaging and the concept of named languages in language education. When typing or texting, your smartphone allows you to change or switch languages simply by pressing a key and switching your keyboard, following the concept that there are named languages. But when bilingual speakers use their phones to text with other bilinguals, they use their entire language repertoire of features, their own language, with some words and phrases associated with one named language and other words and phrases associated with the other. The result is that the smartphone autocorrects words in one language to words in that of the language you're typing in, often to very frustrating - or humorous - effect! Translanguaging is the ability to precisely ignore this kind of language function on the smartphone, and to use all language features fluidly because they are part of the bilingual speaker's repertoire. The reality is that bilinguals communicate without regard to whether their language features are categorized as belonging to one language or another. However, society - and most importantly, the school - educates bilinguals according to a named-language view, not this translanguaging view.

Therefore, translanguagings are multiple linguistic and discursive practices in which bilinguals engage, so that they can make sense of their bilingual worlds and construct meaning (GARCÍA, 2009). Thus, an important aspect of bilingual speakers is that they are not two monolinguals in one person, to this extent, bilingualism is not about $1+1=2$, but about the multiple language repertoire needed to be socially meaningful.

Many bilingual schools try to compartmentalize named languages and have strict policies of languages separation, but when the students are interacting with each other, they tend to violate the language use norms, using languages flexibly in order to support their understandings and building conceptual and linguistic knowledge (GARCÍA, 2009). In order to comprehend the interaction, we need to understand the role of the collaborative learning and its benefits for the development of linguistic repertoire. In short, collaborative learning are events where two or more people learn, or at least, try to learn

\footnotetext{
${ }^{3}$ In the original: "o fator interação é de fundamental importância para qualquer tipo de aprendizagem, especialmente no que diz respeito à aprendizagem de línguas estrangeiras" (my translation).
}

Revista X, v.15, n.1, p. 75-91, 2020. 
together through interactions (FIGUEIREDO, 2006). As Figueiredo (2006) states, collaborative learning is based on principles regarding sociocultural theory, developed by Vygotsky. According to this theory, people are social beings who learn through the interaction with others.

For Vygotsky (1998, cited in FIGUEIREDO, 2006), the interaction of children with adults helps them to develop psychologically and, furthermore, he makes a distinction between two levels of development: the real and the potential. The real development is the ability of children to do tasks by themselves. On the other hand, the potential development is the ability they have to accomplish tasks with the help from adults. The intersection between the two levels of development is called Zone of Proximal Development (ZPD). ZPD emerges from the dialogue and interaction when people engage themselves to accomplish an activity together resulting in cognitive development. Figueiredo (2006, p. 15) explains that "all psychological processes are, initially, social and only later they become individual"

Another important construct in collaborative learning is the scaffolding, which acts like a "supportive structure", and provides the learner with tools or help to solve a task or achieve a goal (FIGUEIREDO, 2006). However, the scaffolding is always temporary. Aljaafreh and Lantolf (1994, cited in FIGUEIREDO, 2006) emphasizes that scaffoldings must be gradual, contingent and dialogic. From this perspective, accepting translanguaging in bilingual classes can be seen as a scaffold in order to provide opportunities for students to use their linguistic repertoire making sense of their interaction with classmates and teachers. Baker (2001, cited in GARCIA; LIN, 2016) identifies four potential educational advantages to translanguaging: a) promote a deeper and fuller understanding of the subject matter; b) help the development of the weaker language; c) facilitate home-school links and cooperation; d) help the integration of fluent speakers with early learners. Therefore, translanguaging practices may be an important tool to allow bilinguals interact using their entire linguistic repertoire to construct knowledge and meaning in classrooms.

Agency in English language teaching can be a means of transforming discursive practices in bilingual education contexts by incorporating new molds, considering, for

\footnotetext{
${ }^{4}$ In the original: "Todos os processos psicológicos são inicialmente sociais e somente mais tarde tornam-se individuais" (my translation).
} 
example, translanguaging rather than a complete separation of the two languages. Translanguaging discursive practices can contribute to a wide use of the student's linguistic repertoire (GARCÍA; WOODLEY, 2015). Regarding translanguaging in prestigious bilingual education, Lucena and Nascimento (2016, p. 54) state that:

Bilingual pedagogy commonly legitimized in prestigious bilingualism scenarios advocates the use of a single language in the classroom. Thus, considering the fact that this type of bilingualism is widespread in Brazil, especially in large and medium-sized urban centers, we argue that translanguaging should also be discussed from this perspective of bilingual education. The production of knowledge in these scenarios can contribute to dispel the monolingual idealizing conception, which advocates the use of one language at a time, and can help students to creatively use their entire linguistic repertoire that includes, among other semiotic resources, their Portuguese.

The authors also point out that translanguaging practices can make the language teaching process less threatening and more collaborative.

When discussion about language teaching in a critical perspective, Pennycook (2001), recognizes that one of the challenges of critical applied linguistics is to find ways to theorize about human agency within power structures and also to theorize about ways of thinking, acting and behaving taking into account social, cultural, economic, ideological and discursive contexts, trying to make room for some possibility of freedom of action and change. Thus, the role of the teacher in the prestigious bilingual context can be to find a balance in his/her classes allowing translanguaging, being aware of the social aspects in which both he/her and his/her students are inserted, creating opportunities for deconstruction and destabilization to happen and promote change.

\section{RESEARCH CONTEXT AND DISCUSSION}

This investigation is grounded in interpretive qualitative research which studies the events in its natural context, seeking to make sense of, or interpret them through meanings people bring to them (DENZIN; LINCOLN, 2018). Therefore, the empirical material for this present study was generated in a prestigious bilingual elementary school (Portuguese/English) in the city of Goiânia, in the state of Goiás, Midwest of Brazil. Nevertheless, it is important to understand bilingual education models and types in order 
to define prestigious bilingual education. Regarding classifications and definitions in bilingual education, Hornberger (1991, cited in GARCÍA, 2009) explains that there is the concept of model, which is a broad category having to do with goals with respect to language, culture, and society; and program types, related to contextual and structural characteristics.

García (2009) states that, traditionally, bilingual education has been classified in monoglossic models (subtractive and additive) and in non-linear heteroglossic ${ }^{5}$ models (recursive and dynamic). The subtractive framework corresponds to the transitional model and considers minority students only as monolingual, sees their bilingualism as a problem to be overcome, as a result, children come to school speaking one language, the school adds a second language, and the children end up speaking the school language, losing their home language (GARCÍA, 2009). The additive framework corresponds to maintenance and enrichment models and works toward the development of the students' bilingualism, understanding bilingualism as an enrichment possibility (GARCÍA, 2009). Recursive bilingualism framework draws on language practices that have almost been silenced, in order to revitalize them focusing on the bilingual continuum of students as they come into classrooms and sees their bilingualism as a right; dynamic bilingualism framework acknowledge that children hold different degrees of bilingualism because of their context (family speaks different languages or have lived in several countries) and accepts their multiple, non-linear, and complex language practices (GARCÍA, 2009). As García (2009, p. 118) highlights, a dynamic theoretical framework "allows the simultaneous coexistence of different languages in communication, accepts translanguaging, and supports the development of multiple linguistic identities". In prestigious bilingual education programs, the aim is to add a second language of prestige, different from the language the students speak at home, thus, this type of education is part of the enrichment model.

In prestigious bilingual education programs, children usually are taught through the medium of two languages of prestige and the languages are clearly separated and their use are often compartmentalized to ensure that children add on a language at the same time

\footnotetext{
${ }^{5}$ Recently sociolinguists have turned to Bakhtin's term 'heteroglossia' to better understand the diversity of linguistic practice in late modern societies. However, the meaning of 'heteroglossia' in not universally or straightforwardly agreed. Heteroglossia as a theoretical term, then, is by definition heteroglossic. As such, it reflects the mobility and flux which is often said to be characteristic of the late modern age (BLACKLEDGE; CREESE, 2014, p. 3-4).
} 
they keep the add-on language distinct from their own ethnolinguistic identity (GARCÍA, 2009). Thus, in the institution where the investigation occurred, the content is taught in Portuguese (mainly the subjects related specifically to Brazil, such as Portuguese, Geography and History) and in English (general subjects such as English, Science and Math). The majority of the students' families lives in expensive neighborhoods in the city and most of the parents are professionals, business executives with high level education. Practically all students are fluent in English, so, despite their young age, they can elaborate most of the answers to the teacher's questions and carry on discussions in English. Although the students are fluent in English, sometimes, they use Portuguese while they are interacting in class. At school they are encouraged to read literary books in English, they have a preparation to take Young Learners English Cambridge exams and a large number of students travel abroad, at least, once a year.

Hence, the empirical material for this present study was generated in one 50minute lesson in two different classes ( $4^{\text {th }}$ and $5^{\text {th }}$ grades). The teacher teaches English and Science for both classes and she planned the lessons in collaboration with me. The $4^{\text {th }}$ grade is a class of 19 students, aged $8-9$, and the $5^{\text {th }}$ grade is a class of 28 students, aged 910. I watched the lessons and recorded them in audio, as the aim of the research was to investigate the use of the L1/ L2 during the students' interaction with the teacher and classmates.

At the beginning of the class, the students watched a video entitled Most sports fans can't point out these World Cup countries on a map...can you? shot on the streets of New York, where the presenter showed some flags of countries competing in the World Cup 2018 and they had to guess the country and where it was located on the map. After watching the video, the teacher asked the students some questions related to it and one of them said:

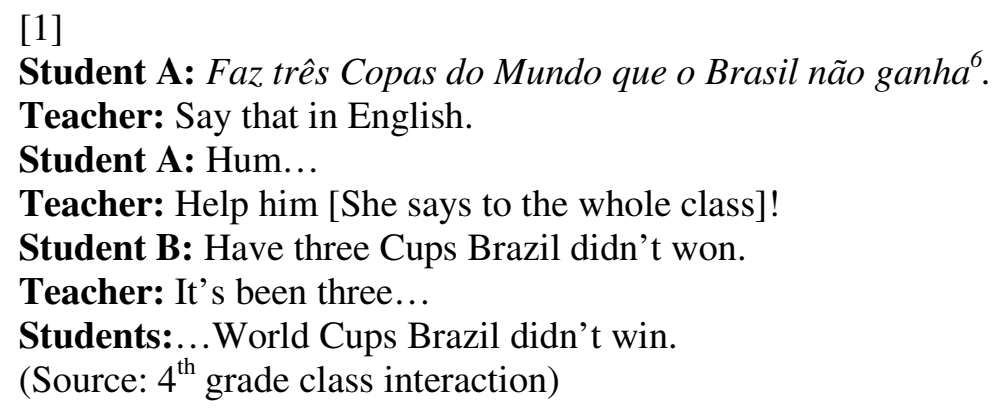

\footnotetext{
${ }^{6}$ Translation: It's been already three World Cups Brazil hasn't won.
} 
Student A makes a comment in Portuguese, and the teacher asks him to repeat that in English, nonetheless, he seems to have some difficulty in elaborating the sentence in English. So, the teacher invites the whole class to help Student A and Student B tries to help him. His sentence still needs accuracy, so the teacher gives him a hint and the students say the sentence more precise. Even being bilingual, Student A does not know how to express himself at that moment in English, then, he says the sentence in Portuguese in order to join the discussion. García (2009, p. 47) affirms that, "bilinguals usually have differentiated use and competence in the languages in which they translanguage", the reason for that can be the amount of exposure to different language practices. Therefore, everybody in class was able to understand him in Portuguese and it was clear that he could comprehend the topic they were discussing, but the teacher, in a kind way, tried to encourage him to attempt speaking the sentence in English.

Thus, in the excerpt 1, we can notice two types of scaffolding: assistance and influence. When the students try to help Student A, they are influencing him; and when the teacher helps him, she is assisting him (FIGUEIREDO, 2006). In the excerpt 2, we can also see an influence scaffolding, once Student D shows Student C how he could say a word in English:

\section{[2]}

Teacher: Why people in the video... most of the people, didn't know where the countries are [on the map]?

Student C: Because the other countries are... como fala desconhecido? ${ }^{7}$ Student D: Not popular.

(Source: $4^{\text {th }}$ grade class interaction)

It is interesting to notice that Student D gives a definition of the word considering the context, not the traditional meaning of the word desconhecido (unknown), and it shows how bilinguals responds to their communicative intent and situation with creativity. The excerpt 2 also presents an example of how translanguaging in the classroom helps students to acquire linguistic repertoire without any intervention from the teacher.

In the excerpt 3, the teacher asks a question and Student $C$ answers in Portuguese, however, when the teacher says the answer in English, Student $\mathrm{C}$ reformulates his answer in the target language. We can notice that the learning does not happen separated from the

\footnotetext{
${ }^{7}$ Translation: ... how do I say unknown? 
performance; it occurs at the time someone is performing (FIGUEIREDO, 2006).

[3]

Teacher: Why is it necessary to divide the teams into groups?

Student C: Se não, vai virar aquela bagunça! ${ }^{8}$

Teacher: Because it's not possible all teams playing against all teams.

Student C: Because it will spend a lot of time.

(Source: $4^{\text {th }}$ grade class interaction)

In this interaction (excerpt 3), although the teacher carries on the conversation in English, she does not translate what Student $\mathrm{C}$ said in Portuguese, it seems unnecessary, and the student understands her point and (re)elaborate his thought. The translanguaging that occurred in the excerpt 3 allowed a meaningful interaction between Student $\mathrm{C}$ and the teacher. Despite curricular arrangements that separate languages and establish the right time to speak Portuguese or English in prestigious bilingual schools, children usually violate the language use norms of the classroom, using languages flexibly to reinforce their understanding and building conceptual and linguistic knowledge (GARCÍA, 2009).

Another interesting event (excerpt 4) shows that, sometimes, the students need to access their L1 to express more elaborated answers:

[4]

Researcher: Do you think money is important to win the World Cup?

Students: No.

Researcher: So, it's not important.

Student C: It's important. I don't know how to say that in English.

Posso responder em português?

Researcher: Yes, you can say that in Portuguese.

Student C: Às vezes o dinheiro pode ajudar, tipo, o Qatar e a Arábia Saudita estão investindo muito dinheiro em esportes, tanto que a Arábia Saudita conseguiu chegar a uma Copa e o Qatar venceu até a Coreia do Sul ${ }^{9}$.

(Source: 4th grade class interaction)

Student $\mathrm{C}$ wanted to express his opinion, but he did not know how to do it in English, so he asked if he could answer in Portuguese. What he wanted to say seemed really complicated to him to be expressed in English. Indeed, Dulay, Burt and Krashen (1982, p. 109) affirm that "learners fall back on the first language when they have not

\footnotetext{
${ }^{8}$ Translation: Because it is going to become a mess!
} 
acquired enough of the second language". Moreover, Student C could join the discussion and the use of his L1 was the reason for that. Many times, students want to be part of the discussion, but if the teacher is strict not allowing any use of the L1 in class, they will be silent. Schweers (1999, cited in NAZARY, 2008) also agrees that the use of an L1 in lessons can influence the classroom dynamic, provides a sense of security and allows students to express themselves. Besides that, translanguaging practices in bilingual classrooms can be a powerful mechanism to construct and mediate understandings, and also to include others (GARCÍA, 2009).

As the discussion goes on, Student D asks the teacher to say her question in Portuguese, once he could not understand it. At first, the teacher hesitates, but then, she uses her Portuguese repertoire to repeat the sentence. This is a good example of Balanced Approach (NAZARY, 2008) and the use of translanguaging in class, especially because she tries not to use her L1, nevertheless, she allows students to participate in the discussion speaking Portuguese and she uses it as scaffolding, so that they can understand better.

\begin{abstract}
[5]
Teacher: So, this is the only inequality that you can notice?

Students: No.

Teacher: Good teams and bad teams, not so good teams in the same group.

Student D: I don't understand. Can you, please, talk in Portuguese?

Teacher: I'm saying... Do you think...hum... what's the inequality? Vocês acham que os países que fazem parte dos grupos aqui... eles têm a mesma chance de ganhar? ${ }^{10}$
\end{abstract}

Students: No.

(Source: $5^{\text {th }}$ grade class interaction)

There are different ways of teaching bilingually. García (2009), refers to three teaching models of bilingual teaching: convergent, immersion and multiple. According to the author, convergent bilingual teaching is the use of the two languages concurrently and the goal of instruction is the development of academic proficiency; immersion bilingual teaching belief is that the two languages are best developed in isolation, this model have a

\footnotetext{
${ }^{9}$ Translation: Sometimes money can help, like, Qatar and Saudi Arabia are investing a lot of money in sports, so that Saudi Arabia managed to get to a World Cup and Qatar won South Korea.

${ }^{10}$ Translation: Do you think that the countries which is part of the groups here... do they have the same chance of winning?
} 
clear and explicit language policy of teaching monolingually for bilingualism and it is often used in prestigious bilingual education; multiple bilingual teaching includes not only the development of bilingual proficiency, but as well as the translanguaging practices, and the two languages are used in combination. The teacher in excerpt 5 is teaching in a context that has strict policies of language separation, and that is the reason she hesitates to speak Portuguese, but once she allows translanguaging in class, the students understand her question and answer her in English. Although some students keep on expressing themselves in their L1, the teacher accepts that and carries on the discussion in English:

\section{[6]}

Teacher: What is this [pointing to the image projected]?

Student E: The rank.

Student F: Eu não sei falar em inglês... é a tabela de quem ganhou mais Copas $^{11}$.

Teacher: So, what is the first country?

Students: Brazil.

(Source: $5^{\text {th }}$ grade class interaction)

In excerpt 6, Student $\mathrm{F}$ shows that he could understand the question in English, but emphasizes that he does not know how to say that in English and negotiate that through translanguaging. The excerpt 7 also brings an example of translanguaging, as the teacher starts her sentence in English, then she adds Portuguese when she says: "So here is... chegou na final mas não venceu, ok?", using Student A conclusion:

[7]

Teacher: Do you remember... no, you don't remember because you weren't born yet, but you have watched on TV... In 1998, Brazil almost won.

Student A: Chegou na final ${ }^{12}$.

Researcher: That's right. That's what we're talking about.

Teacher: So here [in the chart] is ... chegou na final mas não venceu. ${ }^{13}$ Ok?

(Source: $5^{\text {th }}$ grade class interaction)

Furthermore, translanguaging should not be understood as code-switching (which is the act of going back and forth from one language to another), even though it includes

\footnotetext{
${ }^{11}$ Translation: I don't know how to say that in English... this is the table with whom won more Cups.

${ }^{12}$ Translation: Got to the finals.

${ }^{13}$ Translation: ... got to the finals but did not win.
} 
it, but goes beyond code-switching and translation, because it refers to the process by which bilingual students perform bilingually in the myriad multimodal ways of classrooms (GARCÍA, 2009). Thus, the L1 in such scenario helps to clarify some points that the students did not understand, but not only that, it shows how bilingual systems work flowing from L1 to L2 to make sense. What we can notice, though, is that, throughout the world, translanguaging has been used by teachers to scaffold the teaching of a foreign language, and this tool supports language and content learning as students are challenged cognitively but also being provided with contextual and linguistic scaffolds to complete a task or interaction.

\section{FINAL REMARKS}

As mentioned in the introduction, the questions used to guide this study were: a) is it possible to use the students' L1 as a tool/scaffolding to develop their L2?; b) why translanguaging in bilingual classes can be a possibility to enable more heteroglossic linguistic and pedagogy practices? As a matter of fact, the use of Portuguese in English classes should not be seen as an impediment to learn the language, but it can be understood as a scaffolding used by students to negotiate and facilitate the process.

Indeed, what emerged from the investigation was that students resorted to their L1 when they wanted to express themselves but they did not have enough repertoire in the L2. They also used the L1 to ask for clarification, when they could not understand a question, for example. Consequently, translanguage was used as a scaffolding, to help their development and comprehension in the L2. By providing bilingual students with high contextual support or scaffold, meaningful bilingual pedagogy enables students to increasingly perform linguistically. As prestigious bilingual education follows the additive model, which has the goal of add a L2 to the person's repertoire, a new perspective for this type of education can be adopted, providing a blending of language separation with language integration that reflects the dynamic bilingual use and flexibility, as the children appropriate both the content and the language (GARCÍA, 2009). In other words, it is not only an alternation of languages, but a blending of languages that involve the creative process in which the language is used strategically as a set of dynamic linguistic resources to build meanings during interactions (LUCENA; NASCIMENTO, 2016). 
I agree with García and Woodley (2015) when they talk about the importance of considering the use of translanguaging in schools, instead of a strict separation of languages. For the authors,

Translanguaging theory has the potential to transform speakers and listeners, as privilege is taken away from "native speakers" and appropriated by all. By focusing on language features of the speaker's repertoire, and not on named autonomous languages per se, translanguaging has the potential, [...] to provide all learners with equal educational opportunity and build a more just society. (GARCÍA; SELTZER, 2015, p. 21)

Thus, I could not observe negative aspects regarding translanguaging in language education classroom, especially because students appropriate the use of their entire linguistic repertoire, and even though teachers may plan when and how they are going to use a specific language, bilinguals use their repertoires flexibly. According to García (2009), bending and blending ways of languaging bilingually will be crucial in the twentyfirst century. Therefore, rather than focusing on the language itself, translanguaging makes obvious that there are no clear boundaries between the languages of bilinguals.

\section{REFERENCES}

BLACKLEDGE; A. CREESE, A. Heteroglossia as Practice and Pedagogy. In: BLACKLEDGE; A. CREESE, A. (Ed.) Heteroglossia as Practice and Pedagogy. London: Springer, p. 1-20, 2014.

CAZDEN, C.B.; SNOW, C. E. (Eds.). English Plus: Issues in Bilingual Education. The Annals of the American Academy of Political and Social Science, v. 508. London: Sage, 1990.

DENZIN, N. K.; LINCOLN, Y. S. The SAGE handbook of qualitative research. 5. ed. Thousand Oaks: Sage Publications, 2018.

DULAY, H.; BURT, M.; KRASHEN, S. Language two. New York: Oxford, 1982.

KRASHEN, S. D. Principles and Practice in Second Language Acquisition. Oxford: Pergamon Press, 1982.

FIGUEIREDO, F. J. Q. de. Semeando a interação: A revisão dialógica de textos escritos em língua estrangeira. Goiânia: Ed. da UFG, 2005. 
FIGUEIREDO, F. J. Q. de. A aprendizagem colaborativa de línguas: algumas considerações conceituais e terminológicas. In: FIGUEIREDO, F. J. Q. de. (Org.). A aprendizagem colaborativa de línguas. Goiânia: Ed. da UFG, p. 11-45, 2006.

GARCÍA, O. Bilingual Education in the $21^{\text {st }}$ Century: a global perspective. Malden, MA: Wiley-Blackwell, 2009.

GARCÍA, O.; LIN, A. Translanguaging in bilingual education. In: GARCÍA, O. et al. (Eds.). Bilingual and Multilingual Education. Switzerland: Springer, p. 1-24, 2016.

GARCÍA, O.; SELTZER, K. The translanguaging Current in Language Education. 2015. Retrieved from:

<https://ofeliagarciadotorg.files.wordpress.com/2011/02/garcia_seltzer47122073-1.pdf>. Access on: 20 Apr. 2020.

GARCÍA, O.; WOODLEY, H. H. Bilingual education. In: BIGELOW. M.; ENNSERKANANEN, J. (Ed.). The Routledge handbook of educational linguistics. New York: Routledge, p. 132-144, 2015.

HARSEJSANI, R. RAYATI, R. YAQUBI, B. L1 Use and Language-Related Episodes (LREs) in an EFL Setting. The Journal of Teaching Language Skills, v. 3, n. 4, p.100-125, 2012 .

LUCENA, M. I. P.; NASCIMENTO, A. M. Práticas (trans)comunicativas contemporâneas: uma discussão sobre dois conceitos fundamentais. Revista da Anpoll. n. 40, p. 46-57, Florianópolis, 2016.

MCLAUGHLIN, B. Myths and misconceptions about second language learning: what every teacher needs to unlearn. Trabalho subsidiado pelo National Center for Research on Cultural Diversity and Second Language Learning, 1992. Retrieved from: $<$ https://eric.ed.gov/?id=ED352806 > Access on: 30 Apr. 2020.

NAZARY, M. The role of L1 in L2 acquisition: attitudes of Iranian university students. Novitas Royal, v. 2, n. 2, p. 138-153, 2008.

PENNYCOOK, A. Critical Applied Linguistics: a critical introduction. New Jersey: Lawrence Erlbaum Associates, 2001.

Recebido em: 31 out. 2019.

Aceito em: 15 mar. 2020. 